\title{
Pengaturan Hukum Merek Atas Indikasi Geograafis
}

\author{
Budi Agus Riswandi
}

\begin{abstract}
Abstrak
Trade Mark Law in Indonesia has regulated geographical indication. It means, that Indonesia has already hamonized the regulation to the TRIP's system. However, the existence of the rules has not provided optimum protection to the potential geography in Indonesia. One of the Obstacles is the existence of the implementation rule to support the enforcement of geographical indication on the Act No. 15/2001 has not yet issued.
\end{abstract}

\section{Pendahuluan}

Pengaturan hukum merek Indonesia tidak hanya melingkupi pada aspek merek dagang dan merek jasa, namun lingkupnya juga masuk pada pengaturan hukum atas indikasi geografis. ' Pengaturan ini barangkali selain uikarenakan pengaturan indikasi geografis dalam hukum merek ini dapat dibenarkan. Hal ini juga tidak terlepas ada potensi yang dimiliki Indonesia atas indikasi geografis sendiri.

Masalahnya kini, indikasi geografis masih merupakan substansi materi hukum meiek yang belum mendapatkan pengaturan secara menyeluruh, sehingga berakibat pada ketidakefektifan dari aturan indikasi geografis sendiri dalam hukum merek Indonesia. Untuk menggambarkan pendapat ini, di bawah ini akan ditelusuri pengaturan hukum merek atas indikasi geografis dan sekaligus juga memberikan beberapa perbandingan bentuk pengaturan hukum yang ada di negara lain.

\section{Tinjauan Umum atas Indikasi Geografis.}

Kalau melihat website www.wipo.org, sebagai media informasi yang disajikan oleh organisasi kekayaan intelektual dunia, maka dapat ditemukan bahwa masalah hak kekayaan intelektual juga meliputi masalah

${ }^{1}$ Menurut Agung Darmarsasongko dalam tesisnya menyatakan bahwa adanya perbedaan definisi indikasi geografis seringkali mempersulit pemahaman dan penerapannya. Sejauh ini menurutnya, terdapat banyak istilah yang digunakan yang diambil dari nama geografis yang menggambarkan asal barang. Di antaranya; appelation of origin dan indication of geographical origin. Istilah-istilah tersebut sudah digunakan dalam peraturan perundang-undangan di Eropa dan beberapa perjanjian internasional dalam bidang HKI. Lihat Agung Damarsasongko, "Perlindungan Indikasi Geografis di Indonesia," Tesis pada Program Pascasarjana Sekolah Tinggi Ilmu Hukum "IBLAM", Jakarta, 2002,hlm. 5. 
indikasi geografis. Untuk dapat memahami hubungan antara hak kekayaan intelektual dan indikasi geografis dapat ditelusuri dari pemahaman terhadap indikasi geografis itu sendiri. Indikasi geografis dapat diartikan sebagai:2

A geographical indication is a sign used on goods that have a specific geographical origin and possess qualities or a reputation that are due to that place of origin. Most commonly, a geographical indication consists of the name of the place of origin of the goods. Agricultural products typically have qualities that derive from their place of production and are influenced by specific local factors, such as climate and soil. Whether a sign functions as a geographical indication is a matter of national law and consumer perception.

Berdasarkan pengertian di atas, dapat diambil suatu batasan bahwa sesungguhnya indikasi geografis adalah suatu tanda (a sign) pada barang yang mempunyai asal geografis yang spesifik dan mempunyai kualitas atau suatu reputasi yang teruji dari asal tempatnya. Secara garis besar, suatu indikasi geografis meliputi nama, asal tempat dan asal barang. Secara tipikal produk-produk pertanian mempunyai kualitas yang mengarah dari produksi tempat mereka dan dipengaruhi secara spesifik oleh faktor lokal, seperti iklim dan soil. Apapun suatu tanda berfungsi sebagai suatu indikasi geografis merupakan suatu materi hukum nasional dan persepsi konsumen.
WTO memberikan batasan indikasi geografis adalah place names (in some countries also words associated with a place) used to identify the origin and quality, reputation or other characteristics of products (for example, "Champagne", "Tequila" or "Roquefort"). ${ }^{3}$ (nama-nama tempat di beberapa negara juga kata-kata yang diasosiasikan dengan suatu tempat) digunakan untuk mengidentifikasi asal dan kualitas, reputasi atau karakteristik lainnya dari suatu produk, untuk contoh; "Champagne", "Tequila" atau "Roquefort").

Pengertian indikasi geografis juga dapat ditemukan dalam Article 1 (2) the Paris Convention for the Protection of Industrial Property of 1883 yang menyatakan:

The Protection of Industrial Property has its object Patents, Utility Models, Industrial . Designs, Trademarks, Servicesmarks, Tradenames, Indication of Source of Appelation of Origin, and the repression of Unfair Competition.

Indikasi geografis menurut ketentuan Konvensi Paris ini hanya merupakan bagian dari hak kekayaan intelektual. Selanjutnya, pengertian lainnya dapat ditemukan pada ketentuan Article 2 (1) the Lisbon Agreement for the Protection of Appellations of Origin yang menyatakan sebagai berikut:

The geographical name of country, region or locality, which serves to designate a product originating therein the characteristic qualities of which are due exclusively or essentially to geographical environment, including natural and human factor.

Mengacu pada pengertian dari Article 2

${ }^{2}$ WIPO, "Geographical Indications," http:/hwww.wipo.int/about-ip/en/geographical ind,html, diakses tanggal 22 Juni 2004.

${ }^{3}$ WTO,"Geographical Indications," http:/www.wto.org/english/tratop e/trips e/gi e.htm, diakses tanggal 22 Juni 2004. 
(1) Lisbon Agreeement, maka dapat ditarik beberapa kesimpulan, yakni:4

1. Penamaan atas barang/produk harus dengan nama geografis sebuah negara, wilayah atau daerah;

2. Penamaan tempat asal harus menunjukkan bahwa barang atau produk tersebut berasal dari negara, wilayah atau daerah.

3. Harus ada kualitas dan karakteristik pada barang atau produk yang berasal dari daerah geografis tersebut. Kedua hal tersebut merupakan hal yang sangat mendasar dalam menentukan suatu penamaan tempat asal. Kealitas dan karakteristik tersebut ditentukan oleh faktor alam dan manusia.
Indikasi geografis dilindungi oleh hukum nasional dengan konsep batasan yang luas, seperti melalui, ketentuan unfair competion, hukum perlindungan konsumen, hukum merek atau hukum yang secara khusus mengatur indikasi geografis. ${ }^{5}$ Berdasarkan data dari UNCTAD, melindungi indikasi geografis $\mathrm{di}$ beberapa negara ada yang dilakukan; Pertama, melalui Laws Focusing on Business Practices Lawyang, meliputi; unfair competition, misleading of consumers dan passing off; Kedua, melalui Trademark dengan cara pendaftaran merek; dan Ketiga, melalui Special Protection melalui Collective, Certification, Guarantee Marks dan Prior Recognition Requirement. Sebagai gambaran lengkap dapat dicermati pada tabel di bawah ini: ${ }^{6}$

\begin{tabular}{|c|c|c|c|c|c|c|c|c|}
\hline \multicolumn{9}{|c|}{$\begin{array}{c}\text { Tabel } 1 \\
\text { The Legal Means of the Protection of Indications of Geographical Origin }\end{array}$} \\
\hline & \multicolumn{3}{|c|}{$\begin{array}{l}\text { Laws Focusing on Business } \\
\text { Practices (1) Law }\end{array}$} & \multicolumn{2}{|c|}{ Trademark } & \multicolumn{3}{|c|}{ Special Protection } \\
\hline Member & $\begin{array}{l}\text { Focus on } \\
\text { Unfaimess } \\
\text { vis-a-vis } \\
\text { Competitors }\end{array}$ & $\begin{array}{l}\text { Focus on } \\
\text { Misleading of } \\
\text { Consumers }\end{array}$ & $\begin{array}{l}\text { Protection } \\
\text { against } \\
\text { Passing Off }\end{array}$ & \multicolumn{2}{|c|}{\begin{tabular}{|l|} 
Protection against \\
Regristration \\
Trademarks
\end{tabular}} & \begin{tabular}{|l|} 
Collective, \\
Certivication, \\
Guarantee \\
Marks \\
\end{tabular} & \multicolumn{2}{|c|}{\begin{tabular}{|l|} 
Prior \\
Recognition \\
Requiremen \\
(3)
\end{tabular}} \\
\hline & & & \multicolumn{2}{|c|}{ Any IGO } & \multicolumn{2}{|c|}{ Certain IGOs (2) } & No & $\overline{Y e s}$ \\
\hline $\begin{array}{l}\text { Australia } \\
\text { Bulgaria } \\
\text { Canada } \\
\text { Czech Rep. } \\
\text { Ecuador } \\
\text { EC/MS (4) } \\
\text { Austria }\end{array}$ & $\begin{array}{l}x \\
x \\
x \\
x \\
x \\
x \\
x\end{array}$ & $\begin{array}{l}x \\
x \\
x \\
X \\
x \\
x\end{array}$ & $\begin{array}{l}X \\
X\end{array}$ & \begin{tabular}{|c}
$X X$ \\
$X$ \\
$X$ \\
$X X I$ \\
$X X$ \\
$X X$
\end{tabular} & $x($ & $5)^{22}$ & $x x$ & $\begin{array}{l}x \\
x \\
x \\
x \\
x \\
x\end{array}$ \\
\hline
\end{tabular}

${ }^{4}$ Agung Dmarsasongko, Op.,Cit., hlm. 24.

${ }^{5}$ Pengaturan hukum yang secara khusus mengatur indikasi geografis dapat dicontohkan semisal di negara Selandia Baru melalui ketentuan Geographical Indications Act 1994. Lihat Intellectual Property Policy Group," Protection for Geographical Indications in New Zealand," http://www.med.govt.nz/busit/int prop/infosheets/geog-ind.html, diakses tanggal 22 Juni 2004.

${ }^{6}$ Dwijen Rangnekar,"Gegraphical Indications A Review of Proposals at he TRIPs Counsil: Extending Article 20 to Products other than Wines and Spirits," Penelitian pada UNCTAD dan ICTSD, Mei2003, hlm. 28, 


\begin{tabular}{|c|c|c|c|c|c|c|c|c|}
\hline \begin{tabular}{|l|} 
Belgium \\
Denmark \\
Finland \\
France \\
Germany \\
Greece \\
Ireland \\
ltaly \\
Luxembourg \\
Netherlands \\
Portugal \\
Spain \\
Sweden \\
UK \\
Hong Kong, C \\
Hungary \\
Iceland \\
Japan X \\
Korea \\
Liechtenstein \\
Mexico X \\
New Zealand \\
Norway X \\
Peru X \\
Romania X \\
Slovak Rep. X \\
Switzerland X \\
Turkey X \\
USAX \\
Venezuela
\end{tabular} & $\begin{array}{l}X \\
X \\
X \\
X \\
X \\
\cdot \\
X \\
X \\
X \\
X\end{array}$ & $\begin{array}{l}x \\
x \\
x \\
x \\
x \\
x \\
X \\
x \\
x \\
x \\
X \\
x \\
X\end{array}$ & $\begin{array}{l}x \\
x\end{array}$ & 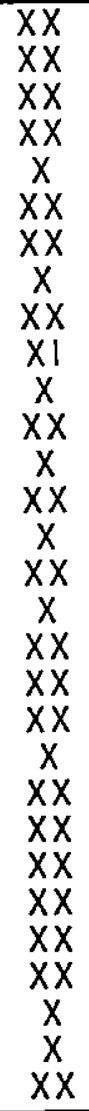 & $\begin{array}{c}x \\
x \\
X(5)\end{array}$ & $x$ & $\begin{array}{c} \\
X \\
? \\
X \\
X \\
x \\
\\
x \\
X \\
X X \\
X X \\
\\
X \\
X \\
X \\
X X \\
X \\
X\end{array}$ & $\begin{array}{r}X X \\
\therefore \\
X \\
X\end{array}$ \\
\hline
\end{tabular}

Sumber. UNCTAD

Keberadaan aturan ini dimaksudkan agar pihak yang tidak mempunyai hak atas indikasi geografis tersebut dilarang untuk menggunakan dan memanfaatkan. Hal ini dimaksudkan juga agar tidak menyesatkan kepada masyarakat konsumen, dimana produk tersebut bukan merupakan produk yang sebenarnya. Hukum yang mengatur indikasi geografis ini lazimnya memuat sanksi dari mulai penetapan sementara pengadilan (court injuction) hingga, ganti kerugian. Dalam kaitannya dengan pengaturan pada hukum nasional dapat dikemukakan contoh sebagai berikut: "Tuscany" untuk olive oil yang diproduksi pada wilayah khusus di ltalia, saat sekarang telah dilindungi oleh Hukum Italia yakni pada Law No. 169 of February 5, 1992), atau "Roquefort" untuk cheese yang diproduksi di Perancis telah dilindungi melalui the European Union under Regulation (EC) No. 2081/92 dan di Amerika Serikat dibawah ketentuan US Certification Registration Mark No. 571.798. ${ }^{7}$

Pada tingkat internasional, indikasi geografis juga telah mendapat beberapa

${ }^{7}$ WIPO, Op.,Cit, diakses tanggal 22 Juni 2004. 
pengaturan dan perlindungan hukum. Hal ini dapat dicermati pada the Paris Convention for the Protection of Industrial Property of 1883 dan the Lisbon Agreement for the Protection of Appellations of Origin and Their Intemational Registration. Selanjutnya dalam kerangka perdagangan internasional indikasi geografis juga diatur dalam Persetujuan TRIPs. Ketentuan yang memberikan perlindungan tersebut terdapat pada ketentuan Section 3 Geographical Indications Article 22 sampai dengan Article 24 TRIPS Agreement.

Adapun persetujuan TRIPs tersebut indikasi geografis dianggap memiliki pengertian yang lebih khusus atau lebih sempit dibandingkan dengan ketentuan Madrid Agreement dan Lisbon Agreement. Dalam persetujuan TRIPs Indikasi Geografis dibatasi hanya tentang perlindungan bagi komoditas yang memiliki ciri-ciri khusus yang dipengaruhi bagi komoditas yang memiliki ciri-ciri khusus yang dipengaruhi oleh faktor alam dan bukan karena faktor manusia. Tradisi dan kerajinan yang dikerjakan dari suatu generasi dari suatu wilayah tidak termasuk dalam materi periindungan. Proses pembuatan tidak termasuk dalam perlindungan meskipun produk tersebut berkaitan dengan budaya dari daerah tersebut. ${ }^{8}$

Terlepas dari hal di atas, keberadaan TRIPs Agreement yang mengatur Indikasi Geografis, ini mempunyai arti yang lebih penting.
Hal ini sejalan dengan yang diungkapkan oleh Sergio Escudero. la menyatakan: ${ }^{9}$

Probably one of the most important effects of the TRIPS Agreement in the area of geographical indications, was precisely that it became the first international treaty, with more than 130 signatories, bound not only to protect geographical indications through substantive provisions but also to enforce its application according to minimum standards. It also provides a strong dispute settlement mechanism under the WTO system. Article 71 of the TRIPS Agreement provides for periodic review and article 23 for renegotiations aimed at increasing the protection of individual geographical indications.

Arti yang lebih penting sebagaimana dinyatakan oleh Sergio Escudero ini di antaranya; Pertama, bahwa TRIPs Agreement pada dasarnya merupakan perjanjian internasional pertama yang ditandatangani oleh 130 penandatangan; Kedua, perlindungan yang diberikan oleh TRIPs Agreement tidak hanya sebatas ketentuan substantif, namun juga meliputi pada aspek penegakkannya berdasarkan standar minimum; Ketiga, penerapan penyelesaian sengketa yang lebih kuat di bawah sistem WTO; Keempat, adanya kesepakatan untuk melaku-kan peninjauan secara periodik untuk pelaksanaan negosiasi ulang dalam upaya meningkatkan perlindung-

${ }^{8}$ Dikutif oleh Agung Damarsasongko dari Albercht Conrad, "The Protection of Geographical Indication in TRIPs Agreement," The International Trademark Association, The Trademark Reporter, January 1996 LexisNexis, him. 5

"Sergio Escudero," International Protection of Geographical Indications and Developing Countries," Makalah disampaikan di the South Centre/Centre for International Environmental Law (CIEL) joint project, funded by the Rockefeller Foundation, to assist developing countries on TRIPs-related issues, hitp:/l www.southcentre.org/publications/geoindication/toc.htm\#TopOfPage, diakses tanggal 22 Juni 2004 
an indikasi geografis individual.

Dengan uraian di atas ini, maka dapat dikemukakan bahwa indikasi geografis telah menjadi suatu perhatian (concern) serius dalam kaitannya dengan masalah hak kekayaan intelektual, baik pada tingkat organisasi internasional maupun negaranegara di dunia. Di samping itu, di sini dapat diketahui secara jelas bahwa baik organisasi internasional maupun negara-negara secara multilateral maupun individual mencoba melakukan upaya-upaya pengaturan terhadap indikasi geografis guna memberikan perlindungan hukum secara maksimal.

\section{Pengaturan Hukum Merek atas Indikasi Geogratis}

Setelah mengetahui indikasi geografis dan pengaturannya, baik pada tingkat internasional maupun nasional di beberapa negara menjadikan hal yang menarik pula untuk menelusuri keberadaan pengaturan indikasi geografis di Indonesia. Indonesia sebagai bagian dari keanggaotaan GATTMTO dan telah meratifikasi Persetujuan Pendirian Organisasi
Perdagangan Dunia (Agreement Establishing World Trade Organization) melalui UU No. 7 Tahun 1994, di mana dalam Persetujuan Pendirian Organisasi Perdagangan Dunia ini ada satu kesepakatan yang menyangkut hak kekayaan intelektual. Kesepakatan itu deikenal dengan istilah Trade Related Aspects of Intellectual Property Right (TRIPs). ${ }^{10}$

Konsekuensi yuridis dari diratifikasinya kesepakatan di atas mendudukan Indonesia sebagai negara yang harus melakukan harmonisasi hukum nasionalnya terhadap kesepakatan-kesepakatan dalam GATT/ WTO, khususnya dalam kaitan ini adalah bidang hak kekayaan intelektual.

Indikasi Geografis merupakan bagian yang tidak terpisahkan dalam TRIPs. Oleh karena itu, indikasi geografis juga merupakan materi yang harus dimasukkan di dalam pengaturan hukum nasional. Dalam hal pengaturan minimal ada dua cara yang dilakukan oleh suatu negara yang telah meratifikasi TRIPs, yakni; Pertama, melakukan pengaturan masalah indikasi geografis di dalam ketentuan hukum lain, semisal merek." Dalam hubungan ini indikasi geografis hanya

${ }^{10}$ TRIPs ini merupakan bagian dari katagori new issues. Isu TRIPs ini diusung oleh negara maju, terutama negara Amerika Serikat yang pada akhirnya disepakati oleh Negara-negara berkembang, termasuk indonesia. Baginegara berkembangyang menyetujui berpendapat bahwa tidak ada jalan lain untukmencegah meningkatnya proteksi selain dengan menyelenggarakan putaran perundingan baru yang di dalamnya termasuk new issues. Namun demikian, ada beberapa negara berkembang yang berhaluan keras menolak untuk diadakan putaran baru apabila new issues khususnya perdagangan jasa dimasukkan dalam agenda perundingan. Negaranegara ini adalah India, Brasil, Yugoslavia dan Mesir.Lihat Taryana Sunandar, Perkembangan Hukum Perdagangan Internasional dari GATT sampai Terbentuknya WTO (World Trade Organization), Departemen Kehakiman, Jakarta, 1995/1996, hlm.119-120.

"Meskipun terkadang indikasi geografis dimasukkan dalam bagian lain dari hak kekayaan intelektual, namun dari segi karakteristik akan senantiasa berbeda. Seperti halnya, pengaturan indikasi geografis dengan merek tentu keduanya ini berbeda sekali. Hal ini dapat dicermati seperti yang dikemukakan oleh WIPO. Menurut WIPO dikatakan: A trademark is a sign used by an enterprise to distinguish its goods and services from those of other enterprises. It gives its owner the right to exclude others from using the trademark. A geographical indication tells consumers that a product is produced in a certain place and has certain characteristics that are 
merupakan bagian saja; Kedua, melakukan pengaturan indikasi geografis dapat saja dilakukan secara tersendiri dalam hukum nasional suatu negara. Artinya aturan tersebut bersifat mandiri.

Dari dua cara ini Indonesia mengambil cara yang kedua. Kesimpulan ini dapat ditarik dengan berlandaskan pada ketentuan Pasal 56 hingga Pasal 58 UU No. 15 Tahun 2001 tentang Merek. ${ }^{12}$ Menurut ketentuan Pasal 56 ayat (1). UU No. 15 Tahun 2001 memberikan penjelasan tentang pengertian indikasi geografis, yakni:

Indikasi geografis dilindungi sebagai suatu tanda yang menunjukkan daerah asal suatu barang, yang karena faktor lingkungan geografis termasuk faktor alam, faktor manusia, atau kombinasi dari kedua faktor tersebut memberikan ciri dan kualitas tertentu pada barang yang dihasilkan.

Pengertian ini memberikan gambaran bahwa yang dikategorikan indikasi geografis menurut aturan hukum Indonesia adalah:

1. Indikasi geografis merupakan suatu tanda;

2. Mienunjukkan daerah asal suatu barang;

3. Disebabkan oleh faktor lingkungan geografis, baik faktor alam, faktor manusia atau kombinasi keduanya;

4. Memberikan ciri dan kualitas tertentu pada barang yang dihasilkan.

Dalam konteks pengaturan hukum atas indikasi geografis di Indonesia suatu indikasi geografis yang memenuhi pengertian yang ada pada ketentuan Pasal 56 ayat (1) UU No.
15 Tahun 2001 tidak dapat secara serta merta dilindungi oleh hukum Indonesia apabila tidak dilakukan pendaftaran sebelumnya. Artinya indikasi geografis di Indonesia menganut sistem first to file principle. Hal ini sejalan dengan ketentuan Pasal 56 ayat (2) UU No. 15 Tahun 2001 yang berbunyi:

Indikasi geografis mendapat perlindungan ' hukum setelah terdaftar atas dasar permohonan yang diajukan oleh:

a. Lembaga yang mewakili masyarakat di daerah yang memproduksi barang yang bersangkutan, yang terdiri atas:

1). Pihak yang mengusahakan barang yang merupakan hasil alam atau kekayaan alam;

2). Produsen barang hasil pertanian;

3). Pembuat barang-barang kerajinan tangan atau hasil industri; atau

4). Pedagang yang menjual barang tersebut.

b. Lembaga yang diberi wewenang untuk itu; atau

c. Kelompok konsumen barang tersebut.

Aturan di atas, di samping menghendaki adanya pengajuan permohonan indikasi geografis, di dalam aturan tersebut juga dipertegas pihak-pihak yang dapat mengaju-kan permohonan. Menurut aturan itu pula disebutkan tiga pihak yang dapat mengajukan permohonan indikasi geografis. Dalam hal lembaga yang mewakili masyarakat di daerah yang memproduksi barang yang dimaksudkan adalah lembaga yang diberi kewenangan untuk mendaftarkan indikasi geografis dan

due to that place of production. It may be used by all producers who make their products in the place designated by a geographical indication and whose products share typical qualities. WIPO, Op.,Cit., diakses 22 Juni 2004.

${ }^{12}$ UU No. 15 Tahun 2001 tentang Merek selanjutnya di dalam tulisan ini disebut UU No. 15 Tahun 2001 
lembaga itu merupakan lembaga Permerintah atau lembaga resmi lainnya seperti koprasi, asosiasi dan lain-lain.

Selain pengajuan permohonan yang tak kalah penting di dalam proses pendaftaran juga mengenai tahapan pengumuman. Untuk tahapan pengumuman ini secara jelas UU No. 15 Tahun 2001 menyatakan bahwa pengumuman yang berlaku di dalam pendaftaran merek secara mutatis mutandis berlaku pula dalam pengumuman indikasi geografis. ${ }^{13}$

Kemudian, di dalam Pasal 56 ayat $\cdot(4)$ dinyatakan beberapa alasan yang dapat diberikan oleh Dirjen HKI suatu indikasi geografis dapat ditolak pendaftarannya, yakni: 1. Bertentangan dengan moralitas, agama, kesusilaan, ketertiban umum, atau dapat memperdaya atau menyesatkan masyarakat mengenai sifat, ciri, kualitas, asal sumber, proses pembuatan, dan/atau kegunaannya;

2. Tidak memenuhi syarat untuk didaftarkan sebagai indikasi geografis.

Alasan yang diberikan dalam UU No. 15 Tahun 2001 dapat ditarik dua kesimpulan, yaitu; Pertama, bahwa alasan pertama pada dasarnya merupakan alasan umum yang alasan ini juga berlaku untuk pendaftaran bidang-bidang hak kekayaan intelektual lainnya, seperti dalam pendaftaran merek dan desain industri; Kedua, alasan kedua ini dapat didasarkan dengan berlandaskan pada adanya pertentangan dengan indikasi geografis yang disebutkan dalam ketentuan Pasal 56 ayat (1) UU No. 15 Tahun 2001.

Apabila pihak yang mengajukan permohonan merasa tidak puas atas penolakan yang dilakukan oleh pihak Dirjen $\mathrm{HKI}$, pemohon dapat melakukan upaya hukum banding. Upaya banding dilakukan kepada Komisi Banding Merek. Untuk prosedural upaya banding ini dapat berlandaskan pada ketentuan Pasal 30, 31, 32, 33 dan 34 UU No. 15 Tahun 2001.

Jangka waktu perlindungan hukum terhadap indikasi geografis ini tidak didasarkan pada tengah waktu/tempo waktu. Akan tetapi, perlindungan terhadap indikasi geografis sangat ditentukan oleh ciri dan/atau kualitas dari indikasi geografis sendiri. Pasal 56 ayat (7) UU No. 15 Tahun 2001 menyatakan:

Indikasi geografis terdaftar mendapatkan perlindungan hukum yang berlangsung selama ciri dan/atau kualitas yang menjadi dasar bagi diberikannya perlindungan atas indikasi geografis tersebut masih ada.

Perlu diketahui pula, UU No. 15 Tahun 2001 di samping mengatur masalah pengertian indikasi geografis perolehan hak atas indikasi geografis, ternyata mengatur juga pada aspek penegakan hak oleh pemegang hak atas indikasi geografis apabila haknya dilanggar.

Upaya penegakkan hak ini dilakukan dengan mengajukan gugatan terhadap pemakai indikasi geografis yang tanpa hak berupa permohonan ganti rugi dan penghentian penggunaan serta pemusnahan etiket indikasi geografis yang digunakan secara tanpa hak tersebut. Untuk mencegah kerugian yang lebih besar pada pihak yang hanya ditanggar, hakim dapat memerintahkan pelanggar untuk menghentikan kegiatan

${ }^{13}$ Untukmekanisme pengumuman dapat mengacu pada ketentuan Pasal21, Pasal 22, Pasal 23, Pasal 24 dan Pasal 25 UU No. 15 Tahun 2001 
pembuatan, perbanyakan serta memerintahkan pemusnahan etiket indikasi geografis yang digunakan secara tanpa hak tersebut. Konsep ini dikenal dengan istilah courts injunction.

Mencermati aturan normatif di atas, maka dapat disimpulkan pengaturan terhadap indikasi geografis telah ada di dalam sistem hukum nasional Indonesia. Artinya upaya harmonisasi terhadap TRIPs Agreement oleh Indonesia sudah dilakukan. Namun demikian, patut dicatat bahwa upaya harmonisasi ini sebatas memenuhi standar internasional, sementara aplikasi/penerapan aturan indiaksi geografis sendiri bagi kepentingan nasional masih cenderung setengah hati. Alasan yang dapat dijadikan dasar senantiasa klasik, yakni tidak tuntasnya pengaturan indikasi geografis sampai kepada aturan hukum pelaksananya. ${ }^{14}$ Sehingga, aturan ini menjadi tidak efektif bagi pihak-pihak di dalam negeri yang punya kepentingan terhadap perlindungan indikasi geografis yang dimiliki Indonesia.

Harus diakui Indonesia punya banyak potensi untuk bidang ini. Di beberapa daerah sebenarnya sudah cukup banyak produkprưưuik peritaiiian yang punya potensi kearah itu, seperti apel malang di daerah Malang, ubi celembu di daerah Sumedang, salak pondoh di Kabupaten Sleman. Berdasarkan keberadaan aturan hukum indikasi geografis yang tidak tuntas dan tidak memiliki kejelasan dalam pengaturannya, hal ini tentu saja memberi andil bagi terhambatnya potensi produk pertanian yang dapat diindikasikan sebagai . indikasi geografis di Indonesia untuk mendapatkan perlindungan hukum.

Suatu perbandingan dapat diungkapkan dalam konteks perlindungan indikasi geografis di antaranya di Australia dan India. Di Australia indikasi geografis diatur pada tahun 1993. Untuk melaksanakan ketentuan mengenai indikasi goegrafis pada bulan Januari 1994 dibentuk Panitia Indikasi Geografis yang bertugas menentukan nama-nama dan batasbatas Indikasi Geografis di Australia. Panitia ini pula yang akan mengumumkan hasil akhir dari penelitiannya. Pengumuman tersebut juga berkaitan dengan pendaftaran Indikasi Geografis yang memberikan perlindungan bagi nama wilayah indikasi geografis di Australia. Perlindungannya berlaku sejak tanggal pendaftaran indikasi geografis tersebut. ${ }^{15}$

Pihak-pihak yang dapat mengajukan sebagai pemohon Indikasi. Geografis di Australia yaitu: ${ }^{16}$

1. A declared winemakers organization

2. A declared wine grape growers organization

3. An organization representating winemakers in a state of territory.

4. An organization representating growers of wine grapes in a state of territory.

5. A winemaker

6. A grower of wine grapes.

Setiap permohonan indikasi geografis $\mathrm{di}$ Australia di samping mengisi formulir juga dilampiri dengan beberapa hal yaitu: ${ }^{17}$

1. Kriteria kualifikasi: menyebutkan namanama dan alamat-alamat dari 5 kebun

${ }^{14}$ Aturan yang dimasud terletak pada ketentuan Pasal 56 ayat (9) UU No. 15 Tahun 2001 yang menyatakan bahwa ketentuan mengenai tata cara pendaftaran indikasi geografis diatur lebih lanjut dengan Peraturan Pemerintah. Aturan ini kalau dicermati hingga kini belum juga dikeluarkan.

${ }^{15}$ Agung Damarsasongko, Op., Cit., hlm. 55

${ }^{16}$ lbid. 
anggur yang masing-masing lima hektar secara bersamaan dengan bukti produksi 500 ton untuk minum anggur pertahunnya.

2. Uraian tertulis: uraian tertulis secara luas tentang tapal batas dan harus ditulis dengan permohonan.

3. Peta: menunjukkan sebutan, nama dari pembuat peta dan tanggal dikeluarkannya seluruh peta yang dipergunakan yang menggambarkan tapal batas.

4. Sejarah umum atas wilayah: memberikan gambaran secara detail tentang sejarah ditemukan dan pengembangan wilayah tersebut yang dimohonkan indikasi geografis.

5. Tanda-tanda perkembangan anggur: menguraikan tingkatan yang dapat dihitung dan substansi menyangkut formasi geologis atas wilayah, tingkatan cuaca (seperti hujan, sinar matahari, temperatur, kondisi cuaca) perbandingan antara anggur yang berkembang di wilayah yang dimohonkan dengan anggur di daerah lain, tersedianya irigasi dan skema irigasi terhadap perkebunan anggur yang dimohonkan.

6. Rencana pengembangan: secara derail menjelaskan rencana pengembangan dari wilayah tersebut.

7. Penggunaan cara tradisional: menjelaskan secara lengkap keberadaan setiap cara-cara tradisional yang relevan pada wilayah tersebut untuk nama yang digunakan sebelumnya atau pengakuan sebelumnya pada tapal batas wilayah tersebut.

8. Sejarah minum anggur dan buah anggur: menceritakan tentang sejarah wilayah tersebut, perkembangan perkebunan anggur dan pembuatan minuman anggur dari waktu ke waktu, dari pertama kali dikembangkan hingga saat ini, serta menunjukkan sumber sejarah tersebut.

9. Tanda-tanda lainnya: memberikan hal-hal lain yang ingin disampaikan kepada Komite Indikasi Geografis.

10. Komentar umum: memberikan komentar atas permohonan tersebut kepada Komite Indikasi Geografis.

Proses pendaftaran indikasi geografis di Australia dilakukan melalui beberapa langkah, yakni: ${ }^{18}$

1. Permohonan: Panitia Indikasi Geografis, Panitia yang berdasarkan Undang-Undang Australia Wine and Brandy Corporation (AWBC) diberi kuasa untuk menentukan nama dan tapal batas dari indikasi geografis, meskipun hal tersebut berdasarkan inisiatifnya sendiri atau dari pemohon indikasi geografis. Seluruh permohonan ditulis berdasarkan permohonan yang telah tersedia pada kantor Panitia Indikasi Geografis.

2. Evaluasi: di atas tanda terima permohonan dari pemohon, Komite Indikasi Geografis akan mengevaluasi informasi yang telah terdapat dalam permohonan dan akan mengatur konsultasi antara pemohon dengan organisasi lainnya. Sebagai catatan bahwa Komite Indikasi Geografis tidak berwenang menerima meskipun tapal batas atau nama yang diserahkan oleh pemohon.

3. Konsultasi: Komite Indikasi Geografis

\section{7 lbid. \\ ${ }^{18} \mathrm{Ibid}$.}


berkewajiban untuk konsultasi dengan laporan kepada petani anggur dan organisasi pembuat minuman anggur setiap permohonan.

4. Pertimbangan Formal dan Permohonan: Kesimpulan dari konsultasi pendahuluan dan pada saat itu pemohon diundang untuk tampil, kemudian diikuti dengan keputusan semantara oleh Komite Indikasi Geografis.

5. Keputusan Sementara: anggota inti dari Komite Indikasi Geografis berdasarkan undang-undang mengumumkan keputusan sementara yang telah dibuat oleh Komite Indikasi Geografis. Periode pengumuman tidak lebih kurang dari satu bulan sejak tanggal dipublikasikannya keputusan sementara tersebut.

6. Pertimbangan atas Pendapat: Berkaitan dengan pendapat masyarakat atas keputusan sementara tersebut kemudian Komite Indikasi Geografis akan mengevaluasi kembali pendapat dari pemohon. Kedua pendapat tersebut diperbandingkan dan dipertimbangkan untuk diputuskan untuk mengambil keputusan sementara atau mengubah nama tapal batas setelah mendapatkan informasi tambahan dari masyarakat selama proses meminta pendapat masyarakat berlangsung.

7. Konsultasi: Selama proses untuk mendapatkan bahan masukkan dari masyarakat atau pendapat masyarakat, maka Komite Indikasi Geografis dapat melakukan konsulatasi lagi kepada Petani Anggur, organisasi pembuat anggur atau organisasi lainnya atau perorangan yang mengerti akan hal tersebut.

8. Keputusan Akhir: Keputusan akhir hanya dapat dibuat Komite Indikasi Geografis setelah menerima pertimbangan masukanmasukan dari masyarakat. Anggota inti dari Komite Indikasi Geografis memberitahukan tentang keputusan akhir dari Komite Indikasi Geografis. Pemberitahuan tersebut harus berisi tentang pernyataan yang membolehkan setiap orang yang mempunyai kepentingan atau tertarik terhadap permohonan tersebut diajukan ke Pengadilan Administrasi Australia untuk diperiksa ulang atas keputusan akhir tersebut, dan pengajuan tersebut adalah 28 (dua puluh delapan) hari setelah pemberitahuan keputusan akhir diumumkan.

9. Pemeriksaan Ulang: Ketika keputusan akhir telah diajukan ke Pengadilan Administrasi Australia dan permohonan untuk pemeriksaan ulang telah menghasilkan keputusan yang tepat oleh Pengadilan yang menyatakan nama dan tapal batas sudah tepat sebagai Indikasi Geografis Australia maka dapat didaftarkan untuk dilindungi namanya dan dijkuti dengan keputusan Pengadilan yang telah diputuskan.

10. Pendaftaran: Ketika tidak ada keberatan ke Pengadilan Adiminstrasi Australia maka Keputusan akhir atas Indikasi Geografis Australia tersebut melalui Anggota Inti Komite Indikasi Geografis atau oleh Ketua Australia Wine and Brandy Coporation mendaftarkan atas perlindungan nama dan wilayah atas produk Indikasi Geografis serta memberikan dampak perlindungan hukum atas Indikasi Geografis.

Negara lainnya yang telah cukup baik dalam pengaturan indikasi geografis adalah India. Perlindungan terhadap Indikasi Geografis 
di India diatur dalam Geographical Indications of Goods (Registration \& Protection) Act 1999 yang ditetapkan berdasarkan prinsip bahwa suatu Negara tidak akan mendapatkan perlindungan secara timbal balik dengan Negara lain menyangkut kepentingan Indikasi Geografisnya kecuali bila Negara tersebut juga memberikan perlindungan yang sama. Dalam Pasal 2 (e) Undang-Undang tersebut dinyatakan bahwa periindungan terhadap Indikasi Geografis dapat diberikan terhadap; produk-produk pertanian, hasil-hasil alam dan produk-produk manufaktur. ${ }^{19}$

Berdasarkan undang-undang ini di India dibentuk suatu badan yang bertugas mengadministrasikan pendaftaran Indikasi Geografis yang dinamakan Geghraphical Indications Registry. Suatu pendaftaran yang telah disetujui mendapatkan sertifikat Indikasi Geografis yang dapat digunakan sebagai bukti keabsahan Indikasi Geografis dan dapat digunakan dalam setiap perkara di persidangan tanpa diperlukan tambahan bukti lain. Selain Geographical Indications Registry, di India juga terdapat badan lain yang cukup memperhatikan masalah Indikasi Geografis walaupun tidak semata-mata mengurusi masalah tersebut. Badan ini merupakan badan non pemerintah yang bernama Gene Campaign. Badan ini didirikan pada tahun 1992 yang anggotanya terdiri dari alhi-ahli di berbagai bidang, antara lain; genetika, sosial, hukum, pertanian, ekonomi, lingkungan, media, kebijakan luar negeri, dan aktivis-aktivis lainnya. Tujuan pendirian badan ini adalah untuk melindungi hak-hak masyarakat setempat atas sumber daya alam mereka termasuk di dalamnya pengetahuan tradisional mereka yang dimiliki secara turun temurun. ${ }^{20}$

Dari segi hukum adanya undang-undang ini dan kelembagaan yang memadai menunjukan kesungguhan pemerintah India dalam menyediakan perangkat peraturan yang menyeluruh mencakup seluruh aspek Indikasi Geografis. Berdasarkan pada perbandingan ini terlihat sekali, dari segi perlindungan indikasi geografis ternyata untuk Negara Australia dan India lebih cenderung mengatur Indikasi Geografis di atur dalam ketentuan secara khusus, sedangkan Indonesia justru mengaturnya dalam ketentuan undang-undana merek. Namun demikian, upaya melindungi Indikasi Geografis yang dilakukan di Australia, India dan Indonesia pada prinsipnya sama yakni dengan menggunakan sistem first to file principle atau sistem pendaftaran. Hal yang disasakan dalam perbandingan ini ternyata Indonesia sesungguhnya dalam pengaturan Indikasi Geografis sangat jauh tertinggal di banding dengan dua Negara yang dijadikan bahan perbandingan. Atas dasar itu pula tidak ada salahnya apabila Indonesia mau belajar dari Negara-negara lain yang berkenaan dengan pengaturan Indikasi Geografis. Upaya ini tentunya dalam kerangka memberikan perlindungan yang efektif bagi Indikasi Geografis yang ada di !ndonesia.

\section{Simpulan}

Pengaturan hukum merek atas indikasi geografis di Indonesia sudah ada yang mana hal ini berarti indonesia telah melakukan upaya harmonisasi terhadap TRIPs Agreement. Akan
is $/$ bid.
20 lbid. 
tetapi, keberadaannya belum memberikan perlindungan hukum secara maksimal atas potensi indikasi geografis di indonesia. Salah satu penyebabnya keberadaan aturan pelaksana guna mendukung teroprasionalisasikannya aturan indikasi geografis pada tingkat UU No. 15 Tahun 2001 hingga kini belum ada. Dengan melakukan perbandingan dengan Negara Australia dan India, maka dapat dikemukakan bahwa Indonesia dalam pengaturan indikasi geografisnya memiliki persamaan terutama dalam konteks sistem pendaftaran, akan tetapi secara nyata dalam pandangan keseluruhan pengaturan Indikasi Geografis di Indonesia sangat jauh tertinggal dengan Australia dan India.

\section{Daftar Pustaka}

Ägung Damarsasongko, "Perlindungan Indikasi Geografis di Indonesia," Tesis pada Program Pasca Sarjana Sekolah Tinggi IImu Hukum "IBLAM", Jakarta, 2002.

Albercht Conrad, "The Protection of Geographical Indication in TRIPs Agreement," The Intemational Trademark Association, The Trademark Reporter, January 1996 Lexis-Nexis.
Dwijen Rangnekar,"Gegraphical Indications A Review of Proposals at he TRIPs Counsil: Extending Article 20 to Products other than Wines and Spirits," Penelitian pada UNCTAD dan ICTSD, Mei 2003. Intellectual Property Policy Group," Protection for Geographical Indications in New Zealand," http://www.med.govt.nz/buslt/ int prop/info-sheets/geog-ind.html, diakses tanggal 22 Juni 2004.

Sergio Escudero," International Protection of Geographical Indications and Developing Countries," Makalah disampaikan di the South Centre/Centre for International Environmental Law (CIEL) joint project, funded by the Rockefeller Foundation, to assist developing countries on TRIPs-related issues, http:// www.southcentre.org/publications/ geoindication/toc.htm\#TopOfPage, diakses tanggal 22 Juni 2004.

WIPO, "Geographical Indications," http:// www. wipo.int/about-ip/en/ geographical ind.html, diakses tanggal 22 Juni 2004.

WTO,"Geographical Indications," http:// www.wto.org/english/tratop e/trips e/ gi e.htm, diakses tanggal 22 Juni 2004. UU No. 15 Tahun 2001 tentang Merek 